\title{
Metabolic performance of the squid Lolliguncula brevis (Cephalopoda) during hypoxia: an analysis of the critical $P_{\mathrm{O}_{2}}$
}

\author{
S. Zielinski ${ }^{\mathrm{a}}$, P.G. Lee ${ }^{\mathrm{b}}$, H.O. Pörtner ${ }^{\mathrm{a}, *}$ \\ ${ }^{a}$ Alfred-Wegener-Institut für Polar und Meeresforschung, Biologie I/Ökophysiologie, Columbusstrasse, \\ 27568 Bremerhaven, Germany \\ ${ }^{\mathrm{b}}$ Marine Biomedical Institute, University of Texas Medical Branch, Galveston, TX 77550, USA
}

Received 1 May 1999; received in revised form 21 June 1999; accepted 2 August 1999

\begin{abstract}
Brief squid Lolliguncula brevis are regularly exposed to fluctuating oxygen levels in their shallow coastal environment. To assess hypoxia resistance, animals were exposed for two hours to ambient oxygen partial pressures $\left(P_{\mathrm{O}_{2}}\right)$ between $19.3 \mathrm{kPa}$ (normoxia) and $6.6 \mathrm{kPa}(34.2 \%$ air saturation) at $20 \pm 1{ }^{\circ} \mathrm{C}$. In a second set of experiments, the animals were subjected to a low $P_{\mathrm{O}_{2}}$ of $2.8 \pm 0.3 \mathrm{kPa}(14.5 \pm 1.6 \%$ air saturation) for 15 to $60 \mathrm{~min}$. Subsequently, metabolic, energy and acid-base status were analysed in the mantle tissue. Onset of anaerobic metabolism was observed between 9.4 and $7.9 \mathrm{kPa}$ (48.7 and $40.9 \%$ air saturation), reflecting the critical oxygen tension for this species. The formation of octopine and acetate indicates a simultaneous onset of anaerobic metabolism in both the cytosol and the mitochondria during progressive hypoxia. Concomitantly, an intracellular acidosis developed. During exposure to oxygen partial pressures between 19.3 and $6.6 \mathrm{kPa}$, aerobic and anaerobic processes were sufficient to maintain energy status in the mantle musculature. No significant changes in ATP and phospho-L-arginine (PLA) concentrations were observed. In contrast, both ATP and PLA levels declined significantly after 15 min at an ambient $P_{\mathrm{O}_{2}}$ of $2.8 \pm 0.3 \mathrm{kPa}$. Concomitantly, the Gibb's free energy change of ATP hydrolysis fell to a minimum value of about $-44 \mathrm{~kJ} \cdot \mathrm{mol}^{-1}$, a level suggested to reflect limiting energy availability for cellular ATPases. These results indicate that hypoxia at $2.8 \mathrm{kPa}$ (14.5\% air saturation) rapidly takes Lolliguncula brevis to the limits of performance. However, it is probably capable of withstanding longer periods of moderate hypoxia close to $50 \%$ air saturation $(9.7 \mathrm{kPa})$, enabling the squids to cope with oxygen fluctuations in their shallow estuarine environment or to dive into hypoxic waters by use of their economic jetting strategy. Nonetheless, the critical $P_{\mathrm{O}_{2}}$ is considered to be high compared to other hypoxia tolerant animals, an observation likely related to the high metabolic rate of these squids. (C) 2000 Elsevier Science B.V. All rights reserved.
\end{abstract}

Keywords: Hypoxia; Critical oxygen tension; Anaerobic metabolism; Energy status; Lolliguncula brevis

*Corresponding author. Tel.: +49-471-4831-307; fax: +49-471-4831-149.

E-mail address: hpoertner@AWI-Bremerhaven.de (H.O. Pörtner) 


\section{Introduction}

The geographic range of the brief squid Lolliguncula brevis extends from Maryland on the east coast of North America to the Rio de la Plata, Argentina, and includes the Caribbean Sea and the Gulf of Mexico (Voss, 1956). These animals are able to enter shallow waters of inshore and estuarine environments (Hendrix et al., 1981; Hanlon et al., 1983). Peak abundances of Lolliguncula brevis are found during the summer months in these waters (Dragovich and Kelly, 1962, 1964, 1967; Copeland, 1965; Livingston et al., 1976; Laughlin and Livingston, 1982), at a time of the year when hypoxic water layers are frequently formed nearshore and in bays (Harper et al., 1981; Turner and Allen, 1982; Gaston, 1985; Pokryfki and Randall, 1987). Lolliguncula brevis have indeed been found in hypoxic water (Vecchione, 1991a,b; Vecchione and Roper, 1991). It was even reported to be quite active down to an oxygen partial pressure of $2.1 \mathrm{kPa}$ at temperatures around $25^{\circ} \mathrm{C}$. Furthermore, it was suggested that it dives into hypoxic waters to avoid predators and/or to feed (Vecchione 1991a and personal communications).

Animals prone to experiencing regular periods of hypoxia in their natural habitat exploit a variety of mechanisms to cope with reduced oxygen availability (for review see Grieshaber et al., 1994). Tolerance to progressive hypoxia has frequently been determined by an analysis of the critical oxygen partial pressure $\left(P_{\mathrm{c}}\right)$. In oxyconformers, oxygen consumption declines continuously with falling ambient $P_{\mathrm{O}_{2}}$ and the $P_{\mathrm{c}}$ is characterized by the transition to anaerobic metabolism at low oxygen tensions (Pörtner and Grieshaber, 1993). Oxyregulating animals like Lolliguncula brevis (Wells et al., 1988) can maintain their oxygen consumption independent of ambient $P_{\mathrm{O}_{2}}$ until a critically low oxygen partial pressure is reached. Below this $P_{\mathrm{c}}$ oxygen consumption finally declines and anaerobic metabolism sets in (see Pörtner and Grieshaber, 1993 for review).

In extreme hypoxia many animals show a depression in metabolic rate and can survive by compensating for the deficit in aerobic energy production by the depletion of phosphagens (e.g. phosphocreatine, phospho-L-arginine) and/or by ATP production through anaerobic metabolism (Pörtner and Grieshaber, 1993; van den Thillart et al., 1994). Nonetheless, survival under hypoxic conditions is time limited since eventually the energy status becomes impaired, reflected by a drop in the cellular Gibb's free energy of ATP hydrolysis to possibly limiting levels (Kammermeier, 1987; Pörtner, 1993).

Survival depends on the maintenance of key functions like ventilation. In squid, ventilation and locomotion are coupled through action of the mantle musculature. Oxygen demand of this tissue during swimming is crucial for hypoxia tolerance. Oxygen limitation during swimming is indicated by the onset of anaerobic glycolytical and mitochondrial energy production above a critical swimming speed of 1.5 to 2 mantle lengths $\cdot \mathrm{s}^{-1}$ (Finke et al., 1996). Although comparative data are lacking, this anaerobic threshold is interpreted to be low compared to other species like Illex illecebrosus and Loligo pealei, where, based on an analysis of the maximal sustainable speed, the approximate critical swimming speed would be 3 and 2.5 mantle lengths $\cdot \mathrm{s}^{-1}$, respectively (Webber and O'Dor, 1986; O’Dor and Webber, 1991). 
The question arises which mechanisms characterize hypoxia tolerance in Lolliguncula brevis. Previous work indicates that Lolliguncula brevis uses an economic swimming strategy by cycling between purely aerobic and mixed aerobic, and anaerobic swimming phases. This strategy implies an economized use of aerobic and anaerobic resources and may be helpful when the animals dive into hypoxic waters (Finke et al., 1996). Oxygen availability will nonetheless limit the stay in hypoxic environments. Therefore, the present study was designed to investigate the mode of energy metabolism as it depends on ambient oxygen concentration at $20^{\circ} \mathrm{C}$, with the goal to define a critical oxygen partial pressure. The level of the Gibb's free energy change of ATP hydrolysis was investigated as a parameter that may limit performance of the mantle musculature in hypoxic waters (cf. Pörtner et al., 1996).

\section{Materials and methods}

\subsection{Animals}

Brief squid (Lolliguncula brevis Blainville, 6.8-36.2 g) were caught in March and April, 1995 and in May, 1997, in the Galveston Ship Channel and Galveston Harbour by fishermen of the Marine Biomedical Institute of the University of Texas, Galveston, Texas, USA, and kept in aquaria with recirculating natural sea water under conditions similar to those in the natural habitat $\left(20-25 \%\right.$, at $\left.20-22^{\circ} \mathrm{C}\right)$. The squid were allowed to adjust to the aquarium for at least $48 \mathrm{~h}$. The animals were fed fish and mysid shrimp up until the last $24 \mathrm{~h}$ before the experiment.

\subsection{Control animals}

The collection of control samples $\left(n=5\right.$ for experiments at $P_{\mathrm{O}_{2}}$ between 6.6 and 19.3 $\mathrm{kPa} ; n=4$ for experiments at $P_{\mathrm{O}_{2}}=2.8 \pm 0.3 \mathrm{kPa}$ ) followed the procedure described by Finke et al. (1996). Animals were kept in aerated seawater at 20-24\%o salinity and $20 \pm 1{ }^{\circ} \mathrm{C}$. After 70 to $100 \mathrm{~min}$ of recovery from handling, ethanol was slowly added as an anaesthetic to a maximal concentration of $2 \%(\mathrm{v} / \mathrm{v})$. Muscles samples were obtained using a parallel arrangement of scalpel blades as described by Pörtner et al. (1991a). Tissue samples were freeze-clamped, wrapped in aluminium foil and stored under liquid nitrogen until analysed.

\subsection{Experimental procedures}

Experimental animals $(n=23)$ were kept in a darkened container (volume 2.51 ) supplied with flowing sea water. For the first $30 \mathrm{~min}$, the incoming water was air-saturated to allow the animals to acclimate. Previous work had shown that recovery periods from stress are extremely short in squid, including this species (Pörtner et al. 1993; Finke et al. 1996). Within the next 30 to $45 \mathrm{~min}, P_{\mathrm{O}_{2}}$ was lowered to levels between 16.9 and $6.6 \mathrm{kPa}$ ( 87.5 to $34.2 \%$ air saturation) by mixing air-saturated water 
and water continuously gassed with nitrogen. These waters were drawn from two separate tanks (22 1 and 181 , respectively) by using two roller pumps (Masterflex variable speed console drive with easy load Masterflex pumphead model 7518-10, Cole-Palmer Instrument Company, Niles, Illinois, USA). All containers were kept in a water bath where temperature was regulated to $20 \pm 1^{\circ} \mathrm{C}$. The calculation of the flow required to keep $P_{\mathrm{O}_{2}}$ constant was based on a resting (routine) oxygen consumption rate of Lolliguncula brevis of $21 \mu \mathrm{mol} \mathrm{O}{ }_{2} \cdot \mathrm{h}^{-1} \cdot \mathrm{g}^{-1}$ body mass at $20^{\circ} \mathrm{C}$ (Finke et al., 1996), and an average body mass of $12 \mathrm{~g}$. Flow was set between 100 and $250 \mathrm{ml} \cdot \mathrm{min}^{-1}$ for a fine adjustment of $P_{\mathrm{O}_{2}}$. The $P_{\mathrm{O}_{2}}$ of the outcoming water was measured with an oxygen electrode (YSI 5739 with YSI ${ }^{2}$ Model 58 Dissolved Oxygen Meter, YSI Inc., Yellow Springs, Ohio, USA) at regular intervals. After $2 \mathrm{~h}$ ethanol was added to a final concentration of $2 \%$, and samples were taken as described for control animals.

In a second set of experiments animals $(n=5-7$ per exposure time) were held in a darkened container (volume 41 ) at lower oxygen tensions obtained by gassing the water with a mixture of $10 \%$ air and $90 \%$ nitrogen. For these experiments, the animals were placed into the water at a $P_{\mathrm{O}_{2}}$ of between $4.6 \mathrm{kPa}$ and $5.1 \mathrm{kPa}$ (23.8 to $26.4 \%$ air saturation). After $30 \mathrm{~min}$ the experimental $P_{\mathrm{O}_{2}}$ of $2.8 \pm 0.3 \mathrm{kPa}(14.5 \pm 1.6 \%$ air saturation) was reached and kept constant throughout the experimental period. Ethanol was added after periods of 15, 30, 45 and $60 \mathrm{~min}$, respectively, and samples were taken as described above.

\subsection{Analyses}

Intracellular $\mathrm{pH}\left(\mathrm{pH}_{\mathrm{i}}\right)$ and tissue concentrations of $\mathrm{CO}_{2}\left(C_{\mathrm{CO}_{2}}\right)$ were measured applying the homogenate technique described by Pörtner et al. (1990) using media containing $160 \mathrm{mmol} \cdot 1^{-1}$ potassium fluoride and $1 \mathrm{mmol} \cdot 1^{-1}$ nitrilotriacetic acid. The remaining tissue powder was extracted in perchloric acid following the procedure of Beis and Newsholme (1975), and modified according to Pette and Reichmann (1982). The adenylates ATP, ADP, AMP and succinate and glycerol-3-phosphate were assayed according to Bergmeyer et al. (1983-1986), inorganic phosphate was estimated according to Pörtner (1990), and phospho-L-arginine, arginine and octopine quantities were determined following the procedure of Grieshaber et al. (1978). The concentration of acetate was analyzed with a Dionex LC ion chromatograph (Idstein, FRG). The measurement followed a procedure modified from Hardewig et al. (1991), using 0.125 $\mathrm{mmol} \cdot \mathrm{l}^{-1}$ octane sulphonic acid as eluent. The column was maintained at $40^{\circ} \mathrm{C}$ for the separation. Peaks were monitored with a conductivity detector.

The levels of free ADP and AMP and the Gibb's free energy change of ATP hydrolysis $(\mathrm{dG} / \mathrm{d} \xi)$ were calculated according to Pörtner (1993) and Pörtner et al. (1996), based on the equilibria of arginine kinase and myokinase. Equilibrium constants for both enzymes were corrected for experimental temperatures and $\mathrm{pH}$ dependence as related to changing proton and magnesium binding of the adenylates and the proton turnover of the arginine kinase reaction.

\subsection{Statistics}

Up to second-order polynomial regressions were calculated for the changes in 
metabolite concentrations, $\mathrm{pH}_{\mathrm{i}}, P_{\mathrm{iCO}}$ and $\left[\mathrm{HCO}_{3}^{-}\right]$, with decreasing $P_{\mathrm{O}}$ between 19.3 and $6.6 \mathrm{kPa}$ (100 and $34.2 \%$ air saturation). The decision of whether data were better fitted by linear or second-order regressions was made on the basis of calculated coefficients of determination $\left(r^{2}\right)$. Values from two animals were eliminated from the data set since they were differing significantly from the norm (Pearson and Hartley's and Nalimov's tests). Significance of changes was evaluated at the 5\% level by the analysis of coefficients of determination and by using an $F$-test following an analysis of variance using Statview II (Abacus Concepts). Solid lines in graphs indicate significant regression curves, with broken lines depicting the $95 \%$ confidence interval. When regressions were significant, a critical point of transition to non-steady state metabolism was determined following a method described by Yeager and Ultsch (1989). For this, the data were sorted into descending order using oxygen tension as a key parameter. Then the data were separated into two groups, where the first group contained the points at the highest oxygen partial pressure $(19.3 \mathrm{kPa}$; control values) and the second group the remaining data points. The two groups were compared by one-way analysis of variance (ANOVA) and Student-Newman-Keuls posthoc tests. In a stepwise procedure, the first point from the second group was transferred to the first group and ANOVA was repeated. This procedure was repeated until only five data points were left in the second group. A minimum $p$ was assumed to indicate the $P_{\mathrm{c}}$ between the lowest $P_{\mathrm{O}_{2}}$ of the first data group and the highest $P_{\mathrm{O}_{2}}$ of the second group. ANOVA and Student-Newman-Keuls posthoc tests were also applied for the evaluation of significant changes during exposure to $P_{\mathrm{O}_{2}}=2.8 \pm 0.3 \mathrm{kPa}(14.5 \pm 1.6 \%$ air saturation). $p$-values given throughout the text reflect results from regression analyses unless the note "ANOVA" is given to indicate the use of stepwise ANOVA procedure.

\section{Results}

Data collected at oxygen partial pressures $\left(P_{\mathrm{O}_{2}}\right)$ between 19.3 and $6.6 \mathrm{kPa}$ (100 to $34.2 \%$ air saturation) are depicted in Figs. 1-6. At all of these oxygen tensions animals were able to maintain their position in the water column. When the squids were gently placed into water of 4.6 to $5.1 \mathrm{kPa}$ (23.8 to $26.4 \%$ air saturation) prior to a decrease in $P_{\mathrm{O}_{2}}$ to $2.8 \pm 0.3 \mathrm{kPa}(14.5 \pm 1.6 \%$ air saturation; extreme hypoxia), they initially showed the same behaviour and no jetting owing to handling was visible. Towards the end of exposure to extreme hypoxia, squids were quite inactive and hovered at the bottom of the animal tank. Data collected after $60 \mathrm{~min}$ of extreme hypoxia were included (in brackets) in the figures.

Despite reduced oxygen partial pressures in the ambient water, intracellular $\mathrm{pH}\left(\mathrm{pH}_{\mathrm{i}}\right)$ for most animals was constant above a $P_{\mathrm{O}_{2}}$ of about $10 \mathrm{kPa}$, but below this threshold it started to fall significantly $(p<0.01)$ after two hours of incubation. Similarly, intracellular $P_{\mathrm{CO}}\left(P_{\mathrm{iCO}_{2}}\right)$ and intracellular bicarbonate concentrations declined significantly $(p<0.001$; Fig. 1$)$. In all cases, the transition to significantly lower values occurred when $P_{\mathrm{O}}$ fell to between 10 and $9.4 \mathrm{kPa}$ (ANOVA, $p<0.001$ ). During exposure to extreme hypoxia, $P_{\mathrm{CO}_{2}}$ and bicarbonate values remained at higher levels probably because of the short term nature $(60 \mathrm{~min})$ of the experiment (Table 1).

Two hours of hypoxic exposure at oxygen partial pressure below $10 \mathrm{kPa}$ led to the 

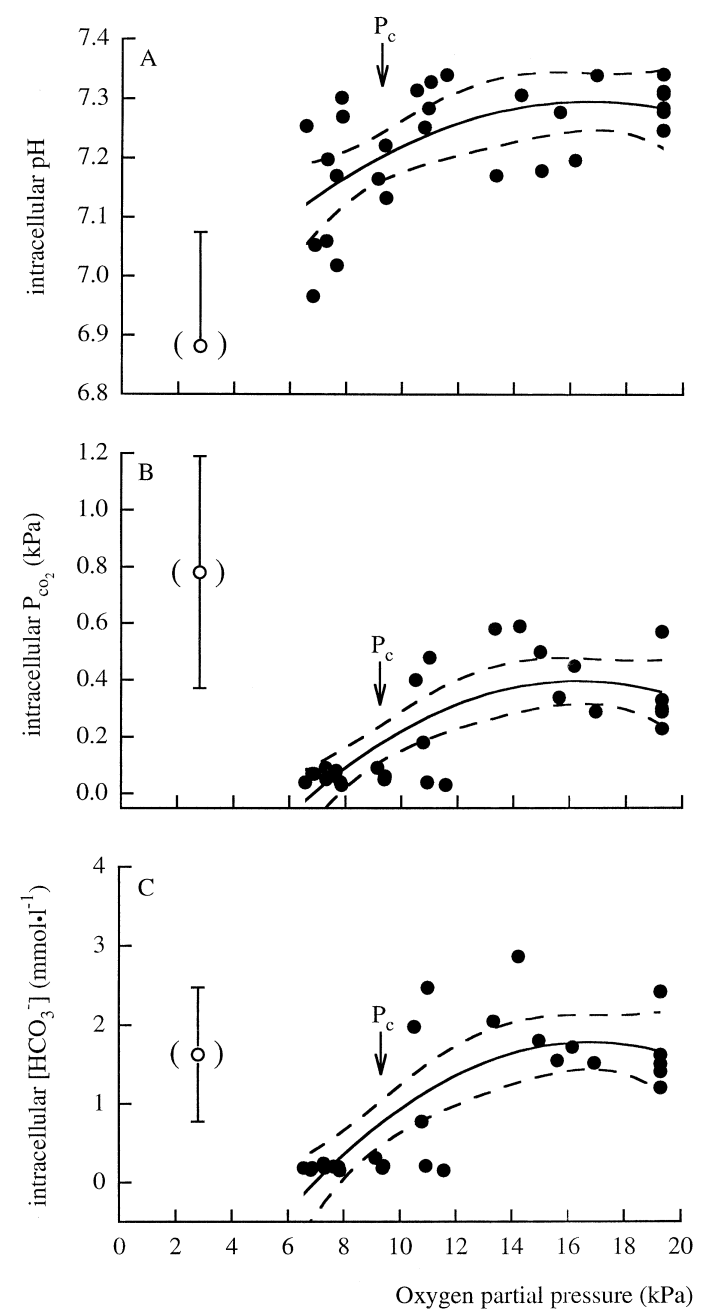

Fig. 1. Changes in (A) intracellular $\mathrm{pH}\left(r^{2}=0.374\right)$; (B) intracellular $P_{\mathrm{CO}_{2}}\left(r^{2}=0.522\right)$; and (C) intracellular $\mathrm{HCO}_{3}^{-}$concentration $\left(r^{2}=0.549\right)$ in the mantle musculature of Lolliguncula brevis, with oxygen partial pressure in the ambient water after $2 \mathrm{~h}$ of exposure. $(n=28$; second-order regressions; solid lines depict a significant trend, short dashed lines the $95 \%$ confidence interval. Values in brackets are means $\pm \mathrm{SD}, n=5$, after $60 \mathrm{~min}$ of exposure to a $P_{\mathrm{O}_{2}}$ of $2.8 \pm 0.3 \mathrm{kPa}$, equivalent to $14.5 \pm 1.6 \%$ air saturation. $P_{\mathrm{c}}$ is indicated as evaluated for the individual process investigated).

significant accumulation of the anaerobic metabolites octopine $(p<0.01)$, glycerol-3phosphate $(p<0.01)$, and acetate $(p<0.05)$ in the mantle musculature of Lolliguncula brevis. Changes in succinate levels remained insignificant, owing to high inter-individual variability ( $p=0.249$; Fig. 2). The onset of anaerobic metabolism at oxygen tensions between $7.9 \mathrm{kPa}$ and $9.4 \mathrm{kPa}$ (ANOVA, $p<0.05$ ) defines the critical $P_{\mathrm{O}_{2}}$. Intracellular $\mathrm{pH}$ decreased significantly with increasing concentrations of octopine $(p<0.001)$, 

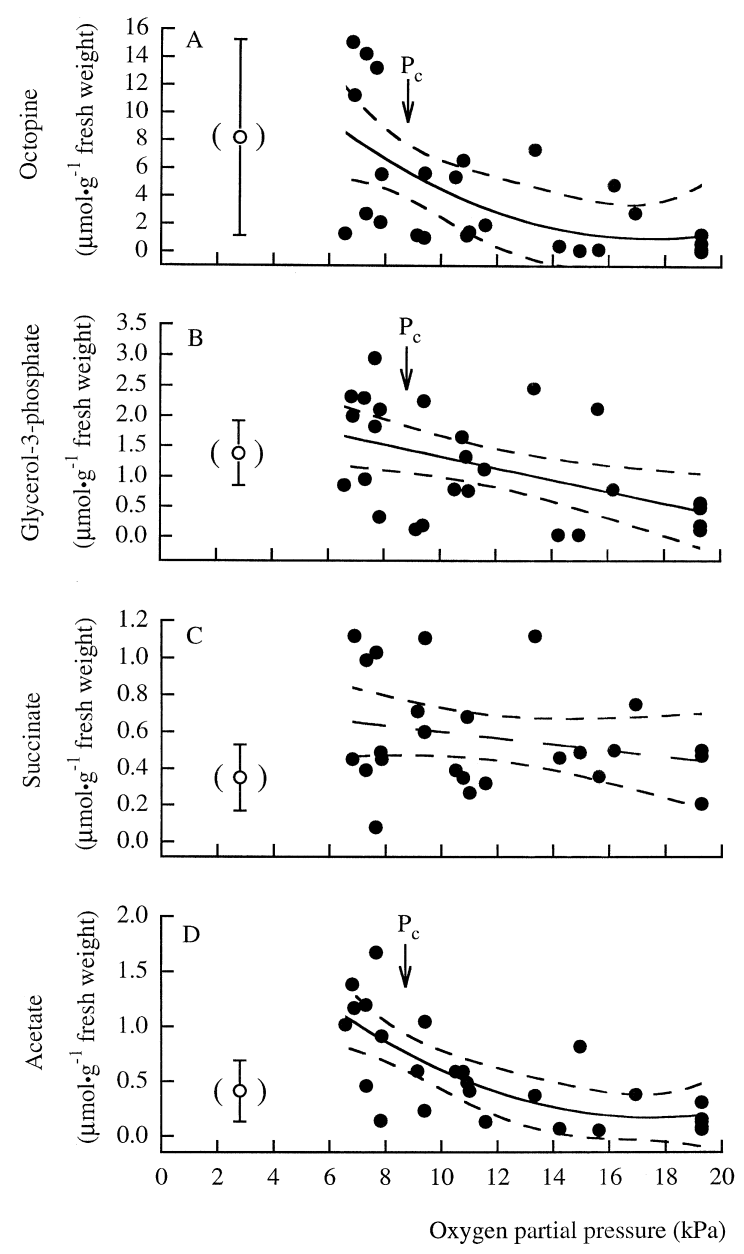

Fig. 2. Changes in (A) octopine $\left(r^{2}=0.390\right)$; (B) glycerol-3-phosphate $\left(r^{2}=0.239\right)$; (C) succinate $\left(r^{2}=0.057\right)$; and (D) acetate $\left(r^{2}=0.302\right)$ levels in the mantle musculature of Lolliguncula brevis with oxygen partial pressure. ( $n=28$; B,C - first-order regressions; A,D - second-order regressions; for further explanation see Fig. 1).

glycerol-3-phosphate $(p<0.01)$, succinate $(p<0.05)$, and acetate $(p<0.001)$, while the Gibb's free energy change of ATP hydrolysis was maintained constant, regardless of a decline in $\mathrm{pH}_{\mathrm{i}}(p=0.164$; Fig. 3). In contrast to these findings, immediate exposure to extreme hypoxia caused only octopine levels to rise significantly after $15 \min (p<0.01)$, whereas the concentrations of the other metabolites, succinate $(p=0.500)$, glycerol-3phosphate $(p=0.483)$, and acetate $(p=0.171)$, did not increase significantly during 60 min of exposure (Table 1 ).

Fig. 4 shows that hypoxic exposure down to $6.6 \mathrm{kPa}$ did not lead to a significant decrease in ATP levels $(p=0.756)$, although the increase in ADP $(p<0.01)$ and AMP $(p<0.01)$ concentrations was significant. As with the change in $\mathrm{pH}_{\mathrm{i}}$, significantly higher 

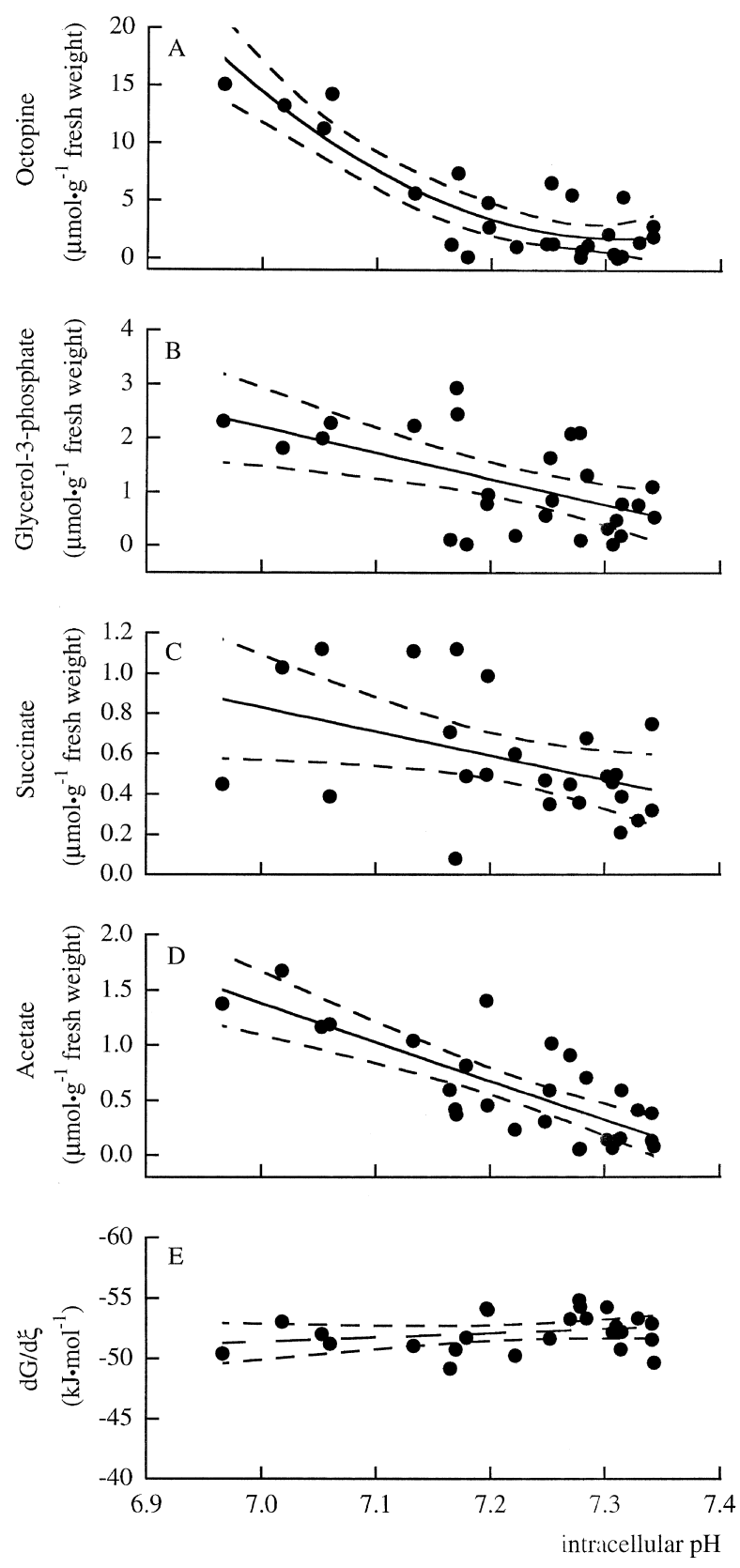

Fig. 3. Intracellular $\mathrm{pH}$ in relation to (A) octopine $\left(r^{2}=0.482\right)$; (B) glycerol-3-phosphate $\left(r^{2}=0.282\right)$; $(\mathrm{C})$ succinate $\left(r^{2}=0.234\right)$; (D) acetate concentrations $\left(r^{2}=0.524\right)$; and (E) the Gibb's free energy change of ATP hydrolysis $\left(r^{2}=0.082\right)$ in the mantle musculature of Lolliguncula brevis after $2 \mathrm{~h}$ of exposure to oxygen partial pressures between 19.3 and $6.6 \mathrm{kPa}(100-34.2 \%$ air saturation). ( $n=28$; B,C,D,E - first-order regressions; A second-order regression). 

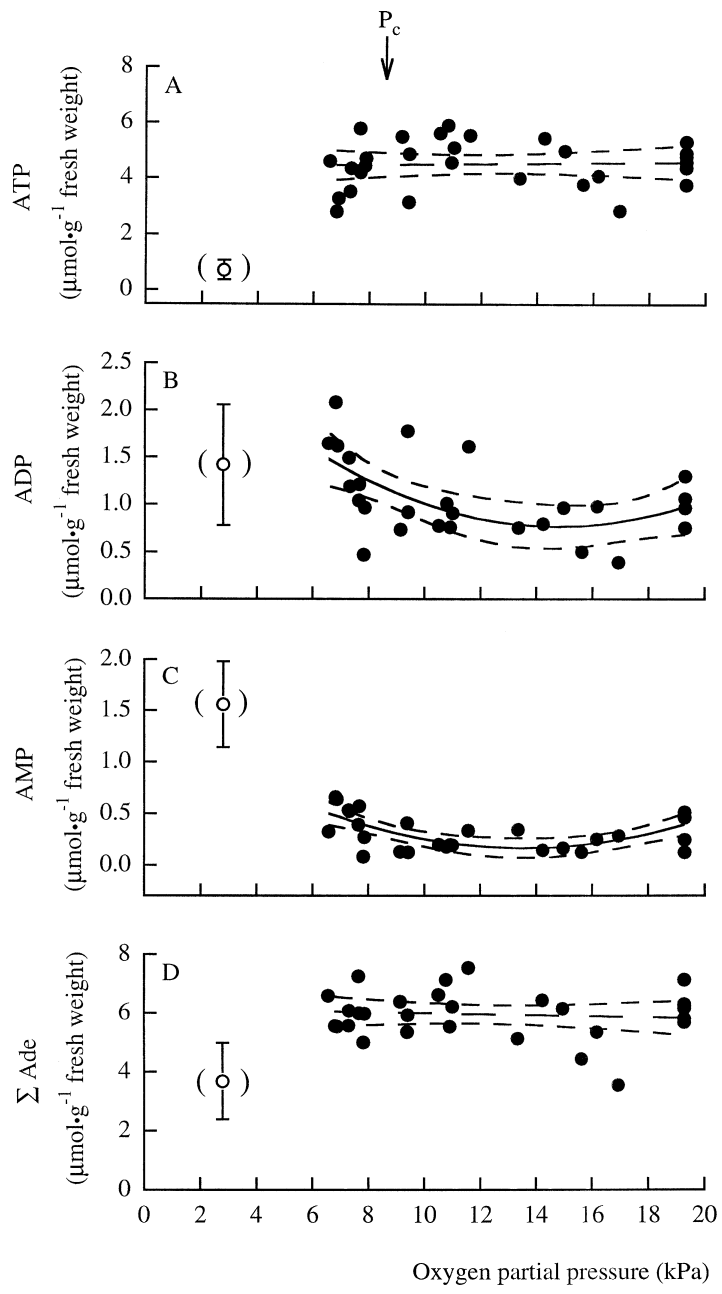

Fig. 4. Changes in (A) ATP $\left(r^{2}=0.004\right)$; (B) ADP $\left(r^{2}=0.312\right)$; (C) AMP $\left(r^{2}=0.387\right)$; and (D) the summed concentrations of all adenylates $\left(\Sigma\right.$ Ade; $\left.r^{2}=0.009\right)$ in the mantle musculature of Lolliguncula brevis with oxygen partial pressure. $(n=28$; A,D - first-order regressions; B,C - second-order regressions; for further explanation see Fig. 1. $P_{\mathrm{c}}$ is indicated as evaluated from concentration changes of anaerobic metabolites as shown in Fig. 2).

ADP and AMP levels were found below a $P_{\mathrm{O}_{2}}$ of 9.1 to $9.4 \mathrm{kPa}$ (ANOVA, $p<0.05$ ). The summed concentrations of the adenylates $(\Sigma \mathrm{Ade}=[\mathrm{ATP}]+[\mathrm{ADP}]+[\mathrm{AMP}])$ remained unchanged $(p=0.633)$. Even under extreme hypoxia, when a significant drop in ATP levels $(p=0.001)$ occurred in parallel with a drastic rise in AMP levels $(p<$ $0.001)$, the drop in $\Sigma$ Ade was still insignificant ( $p=0.160$; Fig. 7, Table 1).

Phospho-L-arginine (PLA) levels did not change at $P_{\mathrm{O}_{2}}$ values between 19.3 and 6.6 $\mathrm{kPa}(p=0.387$; Fig. 5). Accordingly, L-arginine ( $\mathrm{L}-\mathrm{Arg})$ concentrations $(p=0.051)$ and the sum of all L-arginine containing metabolites $\left(\Sigma_{\mathrm{L}-\mathrm{Arg}}=[\mathrm{PLA}]+[\mathrm{L}-\mathrm{Arg}]+[\right.$ octopine $\left.]\right)$ 

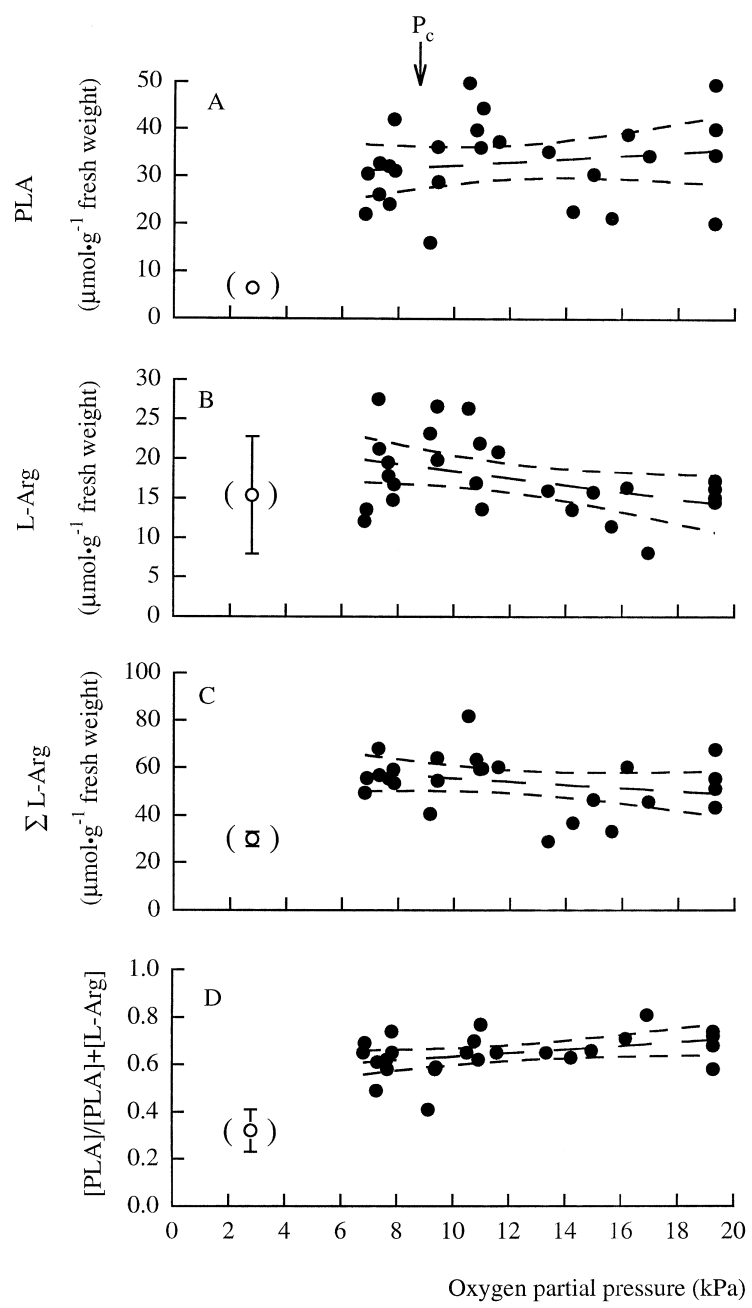

Fig. 5. Levels of (A) phospho-L-arginine $\left(r^{2}=0.031\right)$; (B) L-arginine $\left(r^{2}=0.162\right)$; and (C) the concentrations of all L-arginine containing metabolites $\left(r^{2}=0.064\right)$, as well as (D) the ratio of the levels of phospho-L-arginine over the sum of PLA and L-arginine concentrations $\left(r^{2}=0.138\right)$ in the mantle musculature of Lolliguncula brevis after $2 \mathrm{~h}$ of exposure to various oxygen partial pressures. $(n=28$; first-order regression; for further explanation see Figs. 1 and 4 )

remained more or less constant $(p=0.223)$. These small changes are reflected in an insignificant decrease in the ratio of PLA over the sum of L-Arg and PLA concentrations ( $p=0.061$; Fig. 5). The ratio dropped significantly $(p<0.01)$ to a low value of $0.32 \pm 0.09$ only at a $P_{\mathrm{O}_{2}}$ of $2.8 \pm 0.3 \mathrm{kPa}$ due to significant PLA depletion. Under these conditions even the sum of all L-arginine containing metabolites decreased significantly $(p<0.01$; Table 1).

The small changes in ATP and PLA concentrations at oxygen tensions between 19.3 

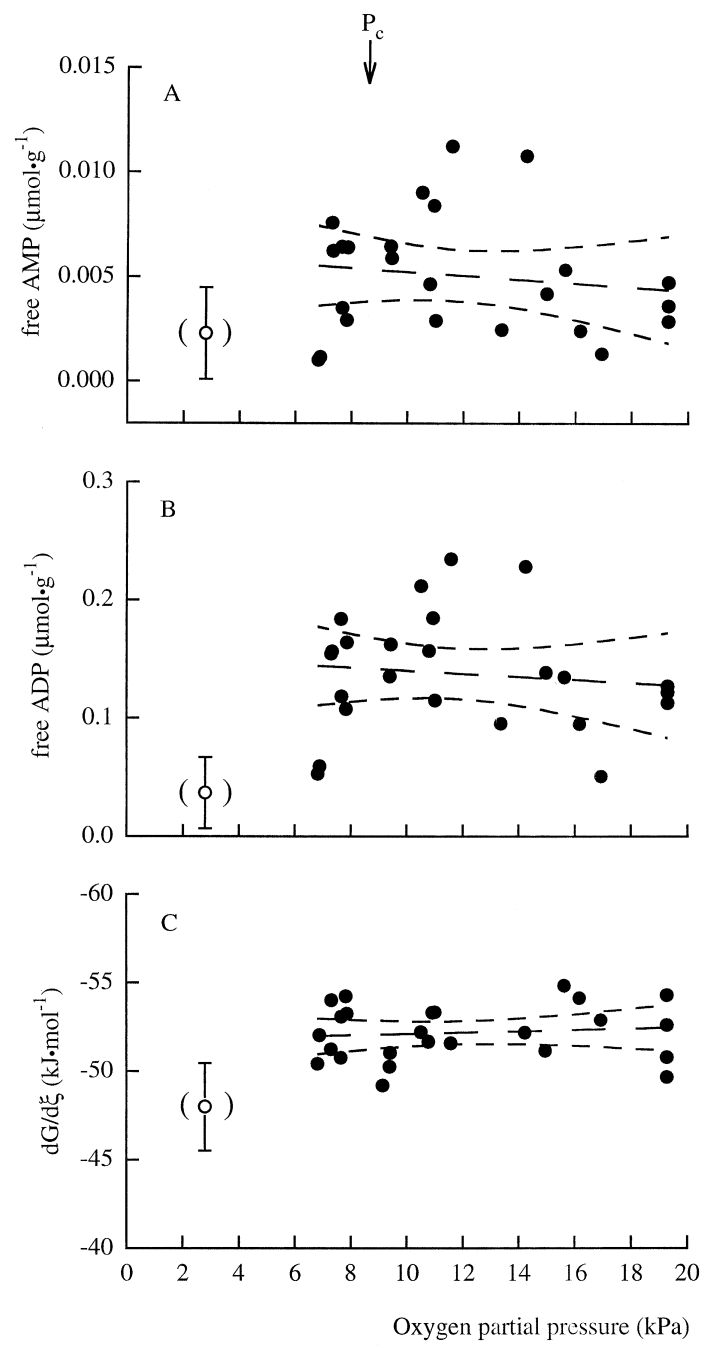

Fig. 6. Levels of (A) free AMP $\left(r^{2}=0.006\right)$; (B) free ADP $\left(r^{2}=0.003\right)$; and $(\mathrm{C})$ the Gibb's free energy change of ATP hydrolysis $\left(r^{2}=0.014\right)$ in the mantle musculature of Lolliguncula brevis after $2 \mathrm{~h}$ of exposure to various oxygen partial pressures. ( $n=28$; first-order regressions; for further explanation see Figs. 1 and 4 )

and $6.6 \mathrm{kPa}$ caused no significant changes in free ADP $(p=0.550)$ and AMP levels $(p=0.604)$ or in the Gibb's free energy change of ATP hydrolysis $(\mathrm{dG} / \mathrm{d} \xi ; p=0.567$; Fig. 6). $\mathrm{dG} / \mathrm{d} \xi$ remained above the value of $-47.99 \pm 2.48 \mathrm{~kJ} \cdot \mathrm{mol}^{-1}$ found during short term exposure to extreme hypoxia (Fig. 7).

Exposure of Lolliguncula brevis to a low $P_{\mathrm{O}_{2}}$ of $2.8 \pm 0.3 \mathrm{kPa}(14.5 \pm 1.6 \%$ air saturation) led to a significant depletion in ATP and PLA concentrations $(p<0.001)$ and a drop in the Gibb's free energy change of ATP hydrolysis $(\mathrm{dG} / \mathrm{d} \xi ; p<0.01)$ during the first 15 mins (Fig. 7). At the same time AMP levels increased significantly $(p<0.001)$ 
Table 1

Intracellular $\mathrm{pH}, P_{\mathrm{CO}_{2}}\left(P_{\mathrm{iCO}} ; \mathrm{kPa}\right)$ and $\mathrm{HCO}_{3}^{-}$levels $\left(\mathrm{mmol} \cdot 1^{-1}\right)$, the ratio of the levels of PLA over the summed concentrations of PLA and L-arginine, and the concentrations $\left(\mu \mathrm{mol} \cdot \mathrm{g}^{-1}\right.$ fresh weight) of various metabolites including the summed levels of L-arginine containing metabolites in the mantle musculature of Lolliguncula brevis during incubation at a $P_{\mathrm{O}_{2}}$ of $2.8 \pm 0.3 \mathrm{kPa}(14.5 \pm 1.6 \%$ air saturation $)$

\begin{tabular}{llllll}
\hline & $\begin{array}{l}0 \mathrm{~min} \\
(n=4)\end{array}$ & $\begin{array}{l}15 \mathrm{~min} \\
(n=7)\end{array}$ & $\begin{array}{l}30 \mathrm{~min} \\
(n=5)\end{array}$ & $\begin{array}{l}45 \min \\
(n=5)\end{array}$ & $\begin{array}{l}60 \min \\
(n=5)\end{array}$ \\
\hline $\mathrm{pH}_{\mathrm{i}}$ & $7.28 \pm 0.02$ & $6.90 \pm 0.15^{\mathrm{a}}$ & $6.88 \pm 0.15^{\mathrm{a}}$ & $6.81 \pm 0.22^{\mathrm{a}}$ & $6.88 \pm 0.19^{\mathrm{a}}$ \\
$P_{\mathrm{iCO}}$ & $0.85 \pm 0.18$ & $1.17 \pm 0.38$ & $1.20 \pm 0.58$ & $1.00 \pm 0.50$ & $0.78 \pm 0.41$ \\
$\mathrm{HCO}_{3}^{-}$ & $3.08 \pm 0.55$ & $1.81 \pm 0.66^{\mathrm{a}}$ & $1.87 \pm 0.84^{\mathrm{a}}$ & $0.89 \pm 0.27^{\mathrm{a}}$ & $1.62 \pm 0.85^{\mathrm{a}}$ \\
{$\left[\mathrm{PLA}^{\mathrm{a}} /[\mathrm{PLA}]+[\mathrm{L}-\mathrm{Arg}]\right.$} & $0.67 \pm 0.10$ & $0.37 \pm 0.14^{\mathrm{a}}$ & $0.36 \pm 0.09^{\mathrm{a}}$ & $0.40 \pm 0.14^{\mathrm{a}}$ & $0.32 \pm 0.09^{\mathrm{a}}$ \\
$P_{\mathrm{i}}$ & $7.11 \pm 4.22$ & $20.75 \pm 11.95$ & $22.02 \pm 7.65$ & $25.96 \pm 2.23^{\mathrm{a}}$ & $19.23 \pm 10.92$ \\
$\Sigma$ L-Arg & $45.22 \pm 6.56$ & $31.10 \pm 4.45^{\mathrm{a}}$ & $33.97 \pm 4.17^{\mathrm{a}}$ & $33.34 \pm 7.99^{\mathrm{a}}$ & $29.89 \pm 3.10^{\mathrm{a}}$ \\
$\Sigma$ Ade & $5.80 \pm 0.36$ & $4.52 \pm 1.50$ & $5.26 \pm 1.14$ & $4.97 \pm 1.46$ & $3.68 \pm 1.30$ \\
Octopine & $1.10 \pm 1.06$ & $10.34 \pm 6.54^{\mathrm{a}}$ & $10.85 \pm 3.65^{\mathrm{a}}$ & $16.32 \pm 5.18^{\mathrm{a}}$ & $8.18 \pm 7.06$ \\
Glycerol-3-phosphate & $0.77 \pm 0.42$ & $1.26 \pm 0.80$ & $1.33 \pm 0.48$ & $1.47 \pm 0.61$ & $1.38 \pm 0.53$ \\
Succinate & $0.25 \pm 0.07$ & $0.32 \pm 0.15$ & $0.42 \pm 0.15$ & $0.37 \pm 0.15$ & $0.35 \pm 0.18$ \\
Acetate & $0.17 \pm 0.12$ & $0.47 \pm 0.34$ & $0.56 \pm 0.14$ & $0.55 \pm 0.19$ & $0.41 \pm 0.28$ \\
free ADP & $0.14 \pm 0.07$ & $0.05 \pm 0.04$ & $0.12 \pm 0.11$ & $0.12 \pm 0.10$ & $0.04 \pm 0.03$ \\
\hline
\end{tabular}

${ }^{a}$ Significantly different from values at $0 \mathrm{~min}$; values are means $\pm \mathrm{SD}$.

after $15 \mathrm{~min}$ and inorganic phosphate concentrations rose; the latter change became significant after $45 \mathrm{~min}(p<0.05$; Table 1$)$. Table 1 also confirms that most changes in energy metabolism occurred within 15 min after exposure to extreme hypoxia, followed by minimal changes during longer periods of hypoxia. This may be related to the observation that the animals reduced activity during exposure to extreme hypoxia.

\section{Discussion}

\subsection{Anaerobic metabolism and the critical $P_{\mathrm{O}_{2}}$}

The critical $P_{\mathrm{O}_{2}}\left(P_{\mathrm{c}}\right)$ in oxyregulators can be defined in two ways: (1) the oxygen partial pressure below which oxygen consumption becomes dependent on ambient $P_{\mathrm{O}_{2}}$, and (2) the oxygen partial pressure indicating the point of transition to anaerobic metabolism. Usually these two $P_{\mathrm{c}}$ values are identical (Pörtner and Grieshaber, 1993). $P_{\mathrm{c}}$ values differ between various aquatic species as shown in Table 2 . For example, a $P_{\mathrm{c}}$ value between 8.6 and $6.7 \mathrm{kPa}$ was derived from aerobic-anaerobic transition or oxygen consumption data in the burrowing marine teleost Lumpenus lampretaeformis (Pelster et al., 1988). In the flatfish Solea solea, the $P_{\mathrm{c}}$ ranged between 4.0 and $2.4 \mathrm{kPa}$ (van den Thillart et al., 1994), while the $P_{\mathrm{c}}$ was $6.7 \mathrm{kPa}$ in Octopus vulgaris (Wells and Wells, 1995), and between 7.0 and $4.0 \mathrm{kPa}$ in the bivalve Scapharca inaequivalvis (van den Thillart et al., 1992). In some animals, for example the toad Bufo marinus (Pörtner et al., 1991b), a transient increase in oxygen consumption has been reported to set in at the $P_{\mathrm{c}}$ when anaerobic metabolism starts. This may also be the case in Lolliguncula brevis, 

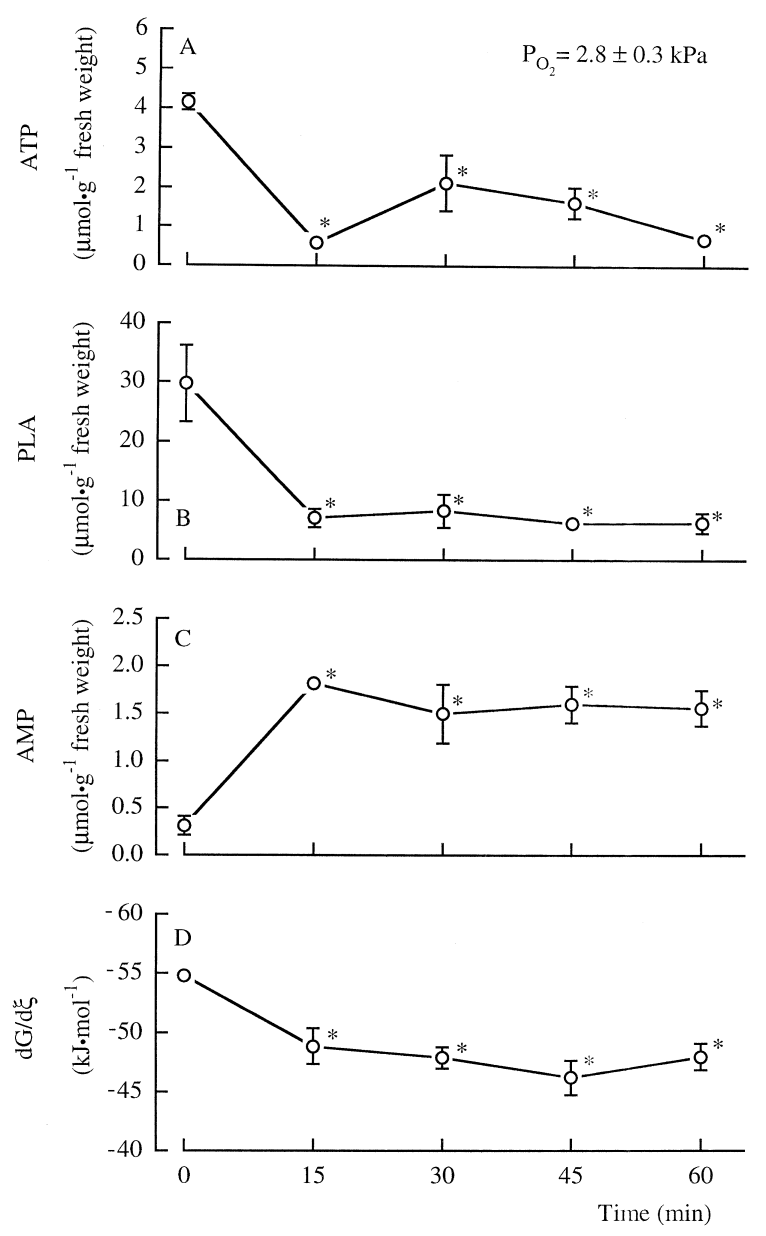

Fig. 7. (A) ATP; (B) phospho-L-arginine; (C) AMP concentrations; and (D) the Gibb's free energy change of ATP hydrolysis in the mantle musculature of Lolliguncula brevis during exposure to a $P_{\mathrm{O}_{2}}$ of $2.8 \pm 0.3 \mathrm{kPa}$. (* - significantly different from values at 0 min; 0 min: $n=4$; 15 min: $n=7$; 30, 45 and 60 min: $n=5$; values are means \pm SD).

which increases its oxygen consumption when ambient $P_{\mathrm{O}_{2}}$ falls to about $7.7 \mathrm{kPa}$ (Wells et al., 1988). The $P_{\mathrm{c}}$ estimated from the onset of anaerobic metabolism in this study ranged between 7.9 and $9.4 \mathrm{kPa}$. A comparison of oxygen consumption data shows that the metabolic rates of Lolliguncula brevis $\left(18.29 \pm 0.80 \mu \mathrm{mol} \mathrm{O}_{2} \cdot \mathrm{h}^{-1} \cdot \mathrm{g}^{-1}\right.$ at $15^{\circ} \mathrm{C}$; Wells et al., 1988) and other squids like Illex illecebrosus $\left(13.96 \mu \mathrm{mol} \mathrm{O}_{2} \cdot \mathrm{h}^{-1} \cdot \mathrm{g}^{-1}\right.$; Webber and O'Dor, 1985, 1986) and Loligo opalescens $\left(11.33 \mu \mathrm{mol} \mathrm{O} \mathrm{O}_{2} \cdot \mathrm{h}^{-1} \cdot \mathrm{g}^{-1}\right.$; O'Dor, 1982) are much higher than the metabolic rates of many other aquatic species (see Table 2) including Octopus vulgaris and Nautilus pompilius. At the same time, the critical oxygen tension for the latter two species (determined by oxygen consumption analysis; Wells and Wells, 1995; Wells, 1990) is lower than that for Lolliguncula brevis. 
Table 2

Critical oxygen tensions $\left(P_{\mathrm{c}}\right)$ and oxygen consumption rates of selected species at temperatures $(\mathrm{T})$ close to $20^{\circ} \mathrm{C}$. Oxygen consumption rates are valid under mormoxia with the exception of Nautilus pompilius where it represents the rate found at $13.3 \mathrm{kPa}$. Furthermore, the weight $(\mathrm{W})$ of animals used for oxygen consumption measurements are given

\begin{tabular}{|c|c|c|c|c|c|c|}
\hline \multirow[t]{2}{*}{ Species } & \multicolumn{2}{|c|}{$P_{\mathrm{c}}(\mathrm{kPa})$ determined by } & \multirow{2}{*}{$\begin{array}{l}\mathrm{M}_{\mathrm{O}_{2}} \\
\left(\mu \mathrm{mol} \mathrm{O} \cdot \mathrm{h}^{-1} \cdot \mathrm{g}^{-1}\right) \\
\text { (control conditions) }\end{array}$} & \multirow{2}{*}{$\begin{array}{l}\mathrm{T} \\
\left({ }^{\circ} \mathrm{C}\right)\end{array}$} & \multirow{2}{*}{$\begin{array}{l}\text { W } \\
(\mathrm{g})\end{array}$} & \multirow[t]{2}{*}{ Reference } \\
\hline & $\begin{array}{l}\text { oxygen } \\
\text { consumption }\end{array}$ & $\begin{array}{l}\text { aerobic-anaerobic } \\
\text { transition }\end{array}$ & & & & \\
\hline \multicolumn{7}{|l|}{ Fishes: } \\
\hline Lumpenus lampretaeformis & $6.7-8.0$ & $\leq 8.6$ & $2.66 \pm 0.41$ & 15 & $4.7-14.3$ & Pelster et al. (1988) \\
\hline Solea solea & & $2.4-4.0$ & & 19 & $70-120$ & van den Thillart et al. (1994 \\
\hline Lepomis macrochirus & & $1.2-2.5$ & & 20 & $51-190$ & Burton and Heath (1980) \\
\hline Ictalurus nebulosus & & $1.2-2.5$ & & 20 & $40-122$ & Burton and Heath (1980) \\
\hline \multicolumn{7}{|l|}{ Invertebrates: } \\
\hline Scapharca inaequivalvis & $4.0-7.0$ & $4.0-7.0$ & $2.3 \pm 0.8$ & 20 & n.a. & van den Thillart et al. (1992 \\
\hline Carcinus maenas & 8.0 & & $1.8 \pm 0.1$ & 18 & $60-80$ & Taylor et al. (1977) \\
\hline Octopus vulgaris & $6.7^{1}$ & & $3.1 \pm 1.4^{2}$ & $\begin{array}{l}19^{1} / \\
22^{2}\end{array}$ & $620-2864$ & $\begin{array}{l}\text { Wells and Wells }(1995)^{1} \\
\text { Houlihan et al. }(1982)^{2}\end{array}$ \\
\hline Nautilus pompilius & $2.7^{3}$ & & $1.0^{4}$ & 18 & $300-450$ & $\begin{array}{l}\text { Wells }(1990)^{3} \\
\text { Boutilier et al. }(1996)^{4}\end{array}$ \\
\hline Lolliguncula brevis & $7.7^{5}$ & $8.6-9.7$ & $21.0^{6}$ & 20 & $6.6-34.2$ & $\begin{array}{l}\text { Wells et al. }(1988)^{5} \\
\text { Finke et al. }(1996)^{6}\end{array}$ \\
\hline
\end{tabular}

${ }^{\mathrm{a}}$ n.a. - data not available.

Therefore, the high oxygen demand even under control conditions in Lolliguncula brevis (Finke et al., 1996) likely explains the high $P_{\mathrm{c}}$ of this species and of squid in general.

Vecchione (1991a) reported Lolliguncula brevis to be quite active in water with a $P_{\mathrm{O}_{2}}$ of $2.1 \mathrm{kPa}$ (10.9\% air saturation) and estimated from catches collected by trawls that Lolliguncula brevis is highly abundant in water with oxygen tensions between 8.6 and $4.3 \mathrm{kPa}$. Furthermore, it has been shown for fish that species with the ability to tolerate hypoxia have lower critical oxygen partial pressures than species which are more sensitive towards hypoxia (Beamish, 1964). Therefore, a lower $P_{\mathrm{c}}$ would have been expected for these squids. However, a rather high $P_{\mathrm{c}}$ was found in our experiments, indicating that Lolliguncula brevis found in the wild at the low oxygen levels reported may be utilizing anaerobic pathways.

The onset of anaerobic metabolism during two hours of exposure to ambient oxygen tensions between 19.3 and $6.6 \mathrm{kPa}$, indicated by the accumulation of octopine and acetate, coincides with a decrease in $\mathrm{pH}_{\mathrm{i}}$ (cf. Fig. 3), since the production of opines, acetate and succinate from glycogen is accompanied by the production of protons (Pörtner, 1987). On the other hand, many aquatic animals increase ventilation during hypoxia to compensate for reduced oxygen availability. This has been shown for example for Octopus briareus (Borer and Lane, 1971) and Octopus vulgaris (Houlihan et al., 1982). The increased gas exchange causes a higher $\mathrm{CO}_{2}$ release into the ambient water resulting in a decrease of $P_{\mathrm{iCO}_{2}}$ as seen for Lolliguncula brevis after $2 \mathrm{~h}$ at oxygen tensions between 19.3 and $6.6 \mathrm{kPa}$. Due to the equilibrium between $\mathrm{CO}_{2}$ and $\mathrm{HCO}_{3}^{-}$, a 
rise in $\mathrm{pH}_{\mathrm{i}}$ would be expected, but a decrease occurred. Obviously, metabolic acidification more than compensates for the respiratory alkalosis.

The extent of succinate and octopine accumulation in Lolliguncula brevis during $2 \mathrm{~h}$ at moderate hypoxia was similar to that seen during exercise above a critical swimming speed (Finke et al., 1996). The finding of a simultaneous onset of anaerobic metabolism in the mitochondria and the cytosol indicates that insufficient oxygen supply to mantle muscle mitochondria elicits anaerobic metabolism both during environmental and functional hypoxia. On the other hand, exposure of Lolliguncula brevis for 15-60 min to an oxygen tension of $2.8 \pm 0.3 \mathrm{kPa}(14.5 \pm 1.6 \%$ air saturation) caused only octopine to accumulate significantly. At oxygen tensions between 19.3 and $6.6 \mathrm{kPa}$, animals stayed in the water column, whereas during extreme hypoxia, many of the squids were quite inactive and hovered at the bottom of their tanks. This behaviour probably resulted in a decrease in metabolic rate and a rise in the fraction of aerobic metabolism (cf. Branco et al., 1993), and would, together with the short exposure period, explain why anaerobic mitochondrial metabolism was not yet visible. Mantle activity was supported by octopine accumulation and the significant depletion of ATP and PLA. AMP and inorganic phosphate accumulation may have contributed to the stimulation of glycolysis resulting in the observed octopine accumulation.

The results of these experiments lead to the conclusion that anaerobic processes are sufficient to support energy production for periods of at least two hours when oxygen tension does not fall below $6.6 \mathrm{kPa}$ (34.2\% air saturation). Considering the findings by Finke et al. (1996) and Pörtner et al. (1996) that anaerobic processes can significantly support swimming of Lolliguncula brevis, the brief squid seems to be able to tolerate fluctuations of oxygen partial pressure in the ambient water to a certain extent and maintain muscular activity. However, when $P_{\mathrm{O}_{2}}$ falls to very low values, high energy phosphates are rapidly depleted and activity is reduced.

\subsection{Gibb's free energy levels}

In many animals hypoxia results in the depletion of energy rich metabolites. For example, phosphocreatine was depleted in the marine teleost Lumpenus lampretaeformis during $7 \mathrm{~h}$ at $15^{\circ} \mathrm{C}$ and $P_{\mathrm{O}_{2}}$ levels below $10.6 \mathrm{kPa}(54.9 \%$ air saturation), thereby buffering ATP levels which remained almost constant (Pelster et al., 1988). Similar results were obtained for the trout Salmo gairdneri after $24 \mathrm{~h}$ at $9^{\circ} \mathrm{C}$ and $P_{\mathrm{O}_{2}}=4 \mathrm{kPa}$ (Boutilier et al., 1988). Exposure of the brief squid Lolliguncula brevis to ambient oxygen partial pressures not lower than $6.6 \mathrm{kPa}(34.2 \%$ air saturation) for $2 \mathrm{~h}$ did not cause a change in PLA levels, while at a $P_{\mathrm{O}_{2}}$ of $2.8 \pm 0.3 \mathrm{kPa}(14.5 \%$ air saturation), both PLA and ATP levels dropped significantly after only $15 \mathrm{~min}$. Such an immediate use of the phosphagen was also found in the goldfish Carassius auratus and the tilapia Oreochromis mossambicus after $30 \mathrm{~min}$ at very low oxygen tensions (van Waarde et al., 1990). In contrast to these species of fish, the level of free ADP did not rise in the squid Lolliguncula brevis during hypoxia, while the concentration of total ADP increased. This observation is consistent with previous findings during exercise (Finke et al., 1996). Obviously, free levels of ADP were buffered, delaying phosphagen hydrolysis and also a 
drop in the Gibb's free energy change of ATP hydrolysis (cf. Pörtner et al., 1996). When the animals were exposed to water with oxygen partial pressures between 19.3 and 6.6 $\mathrm{kPa}\left(34.2-100 \%\right.$ air saturation), $\mathrm{dG} / \mathrm{d} \xi$ remained larger than $-50 \mathrm{~kJ} \cdot \mathrm{mol}^{-1}$ in almost all investigated animals, while at a $P_{\mathrm{O}_{2}}$ of $2.8 \pm 0.3 \mathrm{kPa}$, a minimum value of -44.4 $\mathrm{kJ} \cdot \mathrm{mol}^{-1}$ was calculated. These levels are below the aerobic steady-state energy requirements calculated by Kammermeier (1987) for the function of actomyosinATPase $\left(-45-50 \mathrm{~kJ} \cdot \mathrm{mol}^{-1}\right)$, or sarcolemmal $\mathrm{Ca}^{2+}-$ ATPase $\left(-51 \mathrm{~kJ} \cdot \mathrm{mol}^{-1}\right)$ in rat myocardium. The minimum value found during hypoxia is comparable to a minimum value of $-44 \mathrm{~kJ} \cdot \mathrm{mol}^{-1}$ for Lolliguncula brevis seen during fatigue from exercise (Pörtner et al., 1996). Although a decrease in $\mathrm{dG} / \mathrm{d} \xi$ might be tolerated to a certain extent a fatigue-like situation may result, contributing to the depression of spontaneous activity at extreme hypoxia and limiting hypoxia tolerance.

\subsection{Ecological perspectives}

Similar to Lolliguncula brevis, Nautilus species encounter water layers of low oxygen concentration. These cephalopods have the capacity to survive prolonged periods of low oxygen levels by metabolic depression and a modest reliance on anaerobic energy production as reflected in a small extent of octopine formation. These strategies are accompanied by a decrease in activity and a reduction in ventilatory and circulatory movements (Wells et al., 1992; Boutilier et al., 1996). In Lolliguncula brevis, anaerobic processes also contribute to energy production during hypoxia. The onset of anaerobic metabolism characterized the $P_{\mathrm{c}}$ at a $P_{\mathrm{O}_{2}}$ between 9.4 and $7.9 \mathrm{kPa}(48.7-40.9 \%$ air saturation). Down to an oxygen tension of $6.6 \mathrm{kPa}$ (34.2\% air saturation), aerobic and anaerobic processes appear to be sufficient to maintain a relatively high energy status in the mantle musculature and a normal level of activity. This leads to the conclusion that Lolliguncula brevis has the ability to withstand moderate hypoxia down to $P_{\mathrm{O}_{2}}$ values of around $6.6 \mathrm{kPa}$ for limited periods of time (at least $2 \mathrm{~h}$ ). Only at oxygen tensions of $2.8 \pm 0.3 \mathrm{kPa}(14.5 \pm 1.6 \%$ air saturation), activity levels seemed to decrease thereby lowering the energy demand as seen in Nautilus. Nevertheless, energy requirements could not be met under these conditions and the length of the tolerance period appeared considerably reduced.

Vecchione (1991a) observed these squids to be active in water at a $P_{\mathrm{O}_{2}}$ of about 2.1 $\mathrm{kPa}(10.9 \%$ air saturation) by use of a remotely operated vehicle. He suggested that these squids dive into hypoxic waters to avoid predators and/or to feed. For that purpose they would have to travel at elevated swimming speeds at oxygen tensions below the $P_{\mathrm{c}}$. This appears possible since these animals use an energy saving jetting strategy that involves the cycling between purely aerobic and mixed aerobic and anaerobic swimming phases and allows an extended net use of anaerobic resources before fatigue sets in (Finke et al., 1996; Pörtner et al., 1996). Nevertheless, the critical swimming speed would drop during hypoxia which should accelerate the reduction of energy status. Swimming should therefore limit the time available for excursions into hypoxic layers. In consequence, animals might go into a low activity phase to escape predators, while predation in water with very low oxygen tensions is only possible for very short periods and they would probably have to leave these waters as soon as possible. 


\section{Acknowledgements}

The excellent technical and logistical help by the staff of the Marine Biomedical Institute is gratefully acknowledged. Supported by grants of the Deutsche Forschungsgemeinschaft to H.O. Pörtner (Po 278).

Alfred-Wegener-Institut Publication No. 1668. [SS]

\section{References}

Beamish, F.W.H., 1964. Respiration of fishes with special emphasis on standard oxygen consumption. III. Influence of oxygen. Can. J. Zool. 42, 355-367.

Beis, I., Newsholme, E.A., 1975. The contents of adenine nucleotides, phosphagens and some glycolytic intermediates in resting muscles from vertebrates and invertebrates. Biochem. J. 152, 23-32.

Bergmeyer, H.U., Bergmeyer, J., Graß1, M., 1983-1986. Methods of Enzymatic Analysis, Verlag Chemie, Weinheim.

Borer, K.T., Lane, C.E., 1971. Oxygen requirements of Octopus briareus Robson at different temperatures and oxygen concentrations. J. Exp. Mar. Biol. Ecol. 7, 263-269.

Boutilier, R.G., Dobson, G., Hoeger, U., Randall, D.J., 1988. Acute exposure to graded levels of hypoxia in rainbow trout (Salmo gairdneri): metabolic and respiratory adaptations. Respir. Physiol. 71, 69-82.

Boutilier, R.G., West, T.G., Pogson, G.H., Mesa, K.A., Wells, J., Wells, M.J., 1996. Nautilus and the art of metabolic maintenance. Nature 382, 534-536.

Branco, L.G.S., Pörtner, H.O., Wood, S.C., 1993. Interaction between temperature and hypoxia in the alligator. Am. J. Physiol. 265, R1339-R1343.

Burton, D.T., Heath, A.G., 1980. Ambient oxygen tension $\left(P_{\mathrm{O}_{2}}\right)$ and transition to anaerobic metabolism in three species of freshwater fish. Can. J. Fish. Aquat. Sci. 37, 1216-1224.

Copeland, B.J., 1965. Fauna of the Aransas Pass Inlet, Texas. I. Emigration as shown by tide trap collections. Contrib. Mar. Sci. 10, 9-21.

Dragovich, A., Kelly, Jr. J.A., 1962. A biological study and some economic aspects of squid in Tampa Bay, Florida. Proc. Gulf Caribb. Fish. Inst., 87-103, 15th An. Session.

Dragovich, A., Kelly, Jr. J.A., 1964. Ecological observations of macroinvertebrates in Tampa Bay, Florida 1961-1962. Bull. Mar. Sci. Gulf Caribb. 14, 74-102.

Dragovich, A., Kelly, Jr. J.A., 1967. Occurrence of the squid Lolliguncula brevis, in some coastal waters of western Florida. Bull. Mar. Sci. Gulf Caribb. 17, 840-844.

Finke, E., Pörtner, H.O., Lee, P.G., Webber, D.M., 1996. Squid (Lolliguncula brevis) life in shallow waters: oxygen limitation of metabolism and swimming performance. J. Exp. Biol. 199, 911-921.

Gaston, G.R., 1985. Effects of hypoxia on macrobenthos of the inner shelf off Cameron, Louisiana. Estuar. Coast. Mar. Sci. 20, 603-613.

Grieshaber, M., Kronig, E., Koormann, R., 1978. A photometric estimation of phospho-L-arginine, arginine and octopine using homogenous octopine dehydrogenase isoenzyme 2 from the squid Loligo vulgaris Lam. Hoppe-Seyler's Z. Physiol. Chem. 359, 133-136.

Grieshaber, M.K., Hardewig, I., Kreutzer, U., Pörtner, H.O., 1994. Physiological and metabolic responses to hypoxia in invertebrates. Rev. Physiol. Biochem. Pharmac. 125, 43-147.

Hanlon, R.T., Hixon, R.F., Hulet, W.H., 1983. Survival, growth, and behaviour of the loliginid squids Loligo plei, Loligo pealei, and Lolliguncula brevis (Mollusca: Cephalopoda) in closed sea water systems. Biol. Bull. 165, 637-685.

Hardewig, I., Addink, A.D.F., Grieshaber, M.K., Pörtner, H.O., van den Thillart, G., 1991. Metabolic rates at different oxygen levels determined by direct and indirect calorimetry in the oxyconformer Sipunculus nudus. J. Exp. Biol. 157, 143-160.

Harper, Jr. D.E., McKinney, L.D., Salzer, R.R., Case, R.J., 1981. The occurrence of hypoxic bottom water off the upper Texas coast and its effects on the benthic biota. Contrib. Mar. Sci. 24, 53-79. 
Hendrix, J.P., Hulet, W.R., Greenberg, M.J., 1981. Salinity tolerance and the responses to hypoosmotic stress of the bay squid Lolliguncula brevis, a euryhaline cephalopod mollusc. Comp. Biochem. Physiol. 69A, 641-648.

Houlihan, D.F., Innes, A.J., Wells, M.J., Wells, J., 1982. Oxygen consumption and blood gases of Octopus vulgaris in hypoxic conditions. J. Comp. Physiol. 148, 35-40.

Kammermeier, H., 1987. High energy phosphate of the myocardium: concentration versus free energy change. Basic Res. Cardiol. 82 (2), 31-36.

Laughlin, R.A., Livingston, R.J., 1982. Environmental and trophic determinants of the spatial/temporal distribution of the brief squid (Lolliguncula brevis) in the Apalachicola estuary (North Florida, USA). Bull. Mar. Sci. 32, 489-497.

Livingston, R.J., Kobylinski, G.J., Lewis, F.G., Sheridan, P.F., 1976. Long-term fluctuations of epibenthic fish and invertebrate populations in Apalachicola Bay, Florida. Fish. Bull. 74, 311-321.

O'Dor, R.K., 1982. Respiratory metabolism and swimming performance of the squid, Loligo opalescens. Can. J. Fish. Aquat. Sci. 39, 580-587.

O'Dor, R.K., Webber, D.M., 1991. Invertebrates athletes: tradeoffs between transport efficiency and power density in cephalopod evolution. J. Exp. Biol. 160, 93-112.

Pelster, B., Bridges, C.R., Grieshaber, M.K., 1988. Respiratory adaptations of the burrowing marine teleost Lumpenus lampretaeformis (Walbaum). II. Metabolic adaptations. J. Exp. Mar. Biol. Ecol. 124, 43-55.

Pette, D., Reichmann, H., 1982. A method for quantitative extraction of enzymes and metabolites from tissue samples in the milligram range. J. Histochem. Cytochem. 30, 401-402.

Pörtner, H.O., 1987. Contributions of anaerobic metabolism to pH regulation in animal tissues: theory. J. Exp. Biol. 131, 69-87.

Pörtner, H.O., 1990. Determination of intracellular buffer values after metabolic inhibition by fluoride and nitrilotriacetic acid. Respir. Physiol. 81, 275-288.

Pörtner, H.O., 1993. Multicompartmental analyses of acid-base and metabolic homeostasis during anaerobiosis: invertebrate and lower vertebrate examples. In: Hochachka, P.W., Lutz, P.L., Sick, T., Rosenthal, M., van den Thillart, G. (Eds.), Surviving Hypoxia: Mechanisms of Control and Adaptation, CRC Press, Boca Raton Fl, USA, pp. 139-156.

Pörtner, H.O., Grieshaber, K., 1993. Critical $P_{\mathrm{O}_{2}}$ (s) in oxyconforming and oxyregulating animals: gas exchange, metabolic rate and the mode of energy production. In: Bicudo, J.E.P. (Ed.), The Vertebrate Gas Transport Cascade: Adaptations To Environment and Mode of Life, CRC Press Inc, Boca Raton FL, USA, pp. 330-357.

Pörtner, H.O., Boutilier, R.G., Tang, Y., Toews, D.P., 1990. Determination of intracellular pH and $P_{\mathrm{CO}_{2}}$ after metabolic inhibition by fluoride and nitrilotriacetic acid. Respir. Physiol. 81, 255-274.

Pörtner, H.O., Webber, D.M., Boutilier, R.G., O'Dor, R.K., 1991a. Acid-base regulation in exercising squid (Illex illecebrosus, Loligo pealei). Am. J. Physiol 261, R239-R246.

Pörtner, H.O., MacLatchy, L.M., Toews, D.P., 1991b. Metabolic responses of the toad Bufo marinus to environmental hypoxia: an analysis of the critical $P_{\mathrm{O}_{2}}$. Physiol. Zool. 64, 836-849.

Pörtner, H.O., Webber, D.M., O’Dor, R.K., Boutilier, R.G., 1993. Metabolism and energetics in squid (Illex illecebrosus, Loligo pealei) during muscular fatigue and recovery. Am. J. Physiol. 265, R157-R165.

Pörtner, H.O., Finke, E., Lee, P.G., 1996. Effective Gibb's free energy change of ATP hydrolysis and metabolic correlates of intracellular $\mathrm{pH}$ in progressive fatigue of squid (Lolliguncula brevis) mantle muscle. Am. J. Physiol. 271, R1403-R1414.

Pokryfki, L., Randall, R.E., 1987. Nearshore hypoxia in the bottom water of the northwestern Gulf of Mexico from 1981 to 1984. Mar. Env. Res 22, 75-90.

Taylor, E.W., Butler, P.J., Al-Wassia, A., 1977. Some responses of the shore crab, Carcinus maenas (L.) to progressive hypoxia at different acclimation temperatures and salinities. J. Comp. Physiol. B 122, 391-402.

Turner, R.E., Allen, R.L., 1982. Bottom water oxygen concentration in the Mississippi river delta bight. Contrib. Mar. Sci. 25, 161-172.

van den Thillart, G., van Lieshout, G., Storey, K., Cortesi, P., de Zwaan, A., 1992. Influence of long-term hypoxia on the energy-metabolism of the haemoglobin-containing bivalve Scapharca inaequivalvis: critical $\mathrm{O}_{2}$ levels for metabolic depression. J. Comp. Physiol. 162, 297-304.

van den Thillart, G., Dalla Via, J., Vitali, G., Cortesi, P., 1994. Influence of long-term hypoxia exposure on the energy metabolism of Solea solea. I. Critical $\mathrm{O}_{2}$ levels for aerobic and anaerobic metabolism. Mar. Ecol. Prog. Ser. 104, 109-117. 
van Waarde, A., van den Thillart, G., Erkelens, C., Addink, A., Lugtenburg, J., 1990. Functional coupling of glycolysis and phosphocreatine utilization in anoxic fish muscle. J. Biol. Chem. 265, 914-923.

Vecchione, M., 1991a. Dissolved oxygen and the distribution of the euryhaline squid Lolliguncula brevis. Bull. Mar. Sci. 49, 668-669.

Vecchione, M., 1991b. Observations on the paralarval ecology of a euryhaline squid Lolliguncula brevis (Cephalopoda: Loliginidae). Fish Bull. U.S. 89, 515-521.

Vecchione, M., Roper, C.F.E., 1991. Cephalopods observed from submersibles in the western north Atlantic. Bull. Mar. Sci. 49, 433-445.

Voss, G.L., 1956. A review of the cephalopods of the Gulf of Mexico. Bull. Mar. Sci. Gulf Caribb. 6, 85-178.

Webber, D.M., O'Dor, R.K., 1985. Respiration and swimming performance of short-finned squid (Illex illecebrosus). NAFO Sci. Coun. Studies 9, 133-138.

Webber, D.M., O’Dor, R.K., 1986. Monitoring the metabolic rate and activity of free-swimming squid with telemetered jet pressure. J. Exp. Biol. 126, 205-224.

Wells, M.J., 1990. Oxygen extraction and jet propulsion in cephalopods. Can. J. Zool. 68, 815-824.

Wells, M.J., Wells, J., 1995. The control of ventilatory and cardiac responses to changes in ambient oxygen tension and oxygen demand in Octopus. J. Exp. Biol. 198, 1717-1727.

Wells, M.J., Hanlon, R.T., Lee, P.G., Dimarco, F.P., 1988. Respiratory and cardiac performance in Lolliguncula brevis (Cephalopoda, Myopsida): the effects of activity, temperature and hypoxia. J. Exp. Biol. 138, 17-36.

Wells, M.J., Wells, J., O’Dor, R.K., 1992. Life at low oxygen tensions: the behaviour and physiology of Nautilus pompilius and the biology of extinct forms. J. Mar. Biol. Ass. U.K. 72, 313-328.

Yeager, D.P., Ultsch, G.R., 1989. Physiological regulation and conformation: a BASIC program for the determination of critical points. Physiol. Zool. 62, 888-907. 